\title{
Using spoor counts to analyse the effect of small stock farming in Namibia on caracal density in the neighbouring Kgalagadi Transfrontier Park
}

\author{
H.I.A.S. Melville and J.du P. Bothma
}

\begin{abstract}
A spoor count was done to determine whether caracal spoor densities in the vicinity of the border of the Kgalagadi Transfrontier Park differed from those in the interior of the Park. The objective was to compare caracal densities close to the agricultural land with those deeper in a national park. Two long-distance transects, one along the Namibian border and one diverging from the Namibian border into the interior of the Park, were surveyed on a monthly basis. Spoor density, discrete track set distances and orientation of spoor to the road were recorded and analysed to establish use patterns for three distinct zones in the Park. The hypothesis tested was that increased spoor counts along the border should result from an attraction to the adjacent agricultural (cattle and sheep production) land. It is shown that caracals avoid the areas near the Namibian border during the hot season but increased their utilization in this region in the cold season. This implies that under conditions of low prey availability (cold season) caracals may move to the border and cross onto agricultural land to prey on small livestock, there.
\end{abstract}

\section{Article Outline}

1. Introduction

2. Materials and methods

2.1. Study area

2.2. Methods

2.3. Field study

2.4. Data analysis

3. Results

4. Discussion

5. Conclusions

References

\section{Introduction}

In southern Africa, the caracal Caracal caracal (Schreber, 1776) is regarded as a problem animal (URL: http://lynx.uio.no/catfolk/ssacr101.htm) due to their habitual depredations on small livestock (Stuart and Wilson, 1988). Problem animals are wild animals that persistently and seriously detract from the achievement of man's agricultural endeavours 
(Thomson, 1992). Several studies have confirmed that caracals prey on small domestic livestock to varying degrees (Stuart, 1982; Moolman, 1986; Stuart and Wilson, 1988; Stuart and Hickman 1991; Bothma and Walker, 1999; Melville et al., 2004). In areas where domestic livestock production occurs on land adjacent to conservation areas, there is a definite polarization between agriculturalists and conservationists into two antagonistic camps (Thomson, 1992). This polarization is largely due to the differing attitudes of the two groups to problem animals and their management, especially where larger predators are involved. This antagonistic relationship exists in the southern Kalahari, where a number of Namibian small livestock production units share boundaries with the western parts of the Kgalagadi Transfrontier Park.

From the responses by Namibian farmers to a questionnaire survey conducted during this study, it was clear that the agricultural community believed that predators from the Kgalagadi Transfrontier Park regularly moved across the border onto their land to prey on small livestock, especially during the cold season (Melville, unpublished data). If this were the case, then a higher population density of caracals along the western border of the Kgalagadi Transfrontier Park would have been expected than in the adjacent interior parts of this Park. This hypothesis was tested in this study. To do so, the following key questions were examined:

- Was caracal spoor density significantly higher along the border of the Park than in the interior of the Park?

- Was the intensity of road use by caracal along the border similar to that of the roads in the interior of the Park?

\section{Materials and methods}

\subsection{Study area}

This study was done in an area along the Namibian border near Mata-Mata in the southwestern Kgalagadi Transfrontier Park.

The Kalahari Gemsbok National Park was proclaimed in 1931, but it only became a reality in 1935 when a number of farms along the southern bank of the Aoub River were acquired. Today, the Park exists in much the same ecological state as it was then (Eloff, 1984; van der Walt and le Riche, 1999). An agreement to formally combine the Kalahari Gemsbok National Park (South Africa) with the bordering Gemsbok National Park (Botswana) to form the Kgalagadi Transfrontier Park was signed by representatives of the governments of South Africa and Botswana in 1999. This agreement was ratified in May 2000 (Donaldson, 2000).

Mata-Mata lies in the Shrubby Kalahari Dune Bushveld of the Savanna Biome (Low and Rebelo, 1996). This area is an arid savanna with temperatures varying from -10 to $45^{\circ} \mathrm{C}$ in the shade with an annual mean rainfall of $153.5 \mathrm{~mm}$ occurring mainly in the hot 
season. The landscape consists of undulating dunes with sparse vegetation at altitudes varying from 1000 to $1100 \mathrm{~m}$ above sea level (Low and Rebelo, 1996).

The vegetation is characterized by the trees Acacia erioloba, Acacia haematoxylon and Boscia albitrunca, a shrub layer of Grewia retinervis and Rhus tenuinervis, and a welldeveloped grass layer consisting mainly of Stipagrostis amabilis, Eragrostis lehmanniana, Aristida meridionalis, Schmidtia kalihariensis and Centropodia glauca (Low and Rebelo, 1996). There is little variation in the soil forms because the area is predominantly covered by aeolian sand overlying calcrete (Low and Rebelo, 1996).

\subsection{Methods}

It is difficult to obtain reliable density indices for animals that are nocturnal, camouflaged and cryptic as are most solitary mammalian carnivores (Mahon et al., 1998). Direct sampling is too time-consuming and costly to be seriously considered for monitoring purposes (Smallwood and Fitzhugh, 1994).

Spoor counts are an efficient and low-cost method of estimating species richness and abundance (Litvaitis et al., 1985; Smallwood and Fitzhugh, 1994; Stander, 1998; Silveira et al., 2003). Because of the ease with which caracal spoor can be found and counted on the sandy substrate of the Kalahari, spoor counts were used here to monitor the relative abundance of caracals in various parts of the western Kgalagadi Transfrontier Park. There is a direct relationship between the frequency of spoor and the density in which the animals occur (Tyson, 1959; van Dyke et al., 1986; Stander, 1998; Thompson et al., 1998; Funston et al., 2001).

Here it was necessary to use terminology with definitions specific to the circumstances in which they were used. The following is a list of terms and definitions as they were applied to this study:

- Spoor density: the mean number of sets of caracal tracks per $100 \mathrm{~km}$.

- Spoor ratio: the relative frequency of caracal spoor per $100 \mathrm{~km}$ of tracking over successive counts along the same transect.

- Discrete track sets: a continuous set of caracal tracks along or across a transect.

\subsection{Field study}

Spoor counts were done along management roads because the soft sand was eminently suitable for spoor detection (Funston et al., 2001). Transects were done by vehicle on a monthly basis from June 2001 to July 2002, with the assistance of experienced Kalahari San trackers. These trackers are highly accurate and reliable when identifying and interpreting animal tracks (Stander et al., 1997). This trait was important in the Kalahari, where caracals coexist with other felids including; lion Panthera leo, leopard Panthera pardus, cheetah Acinonyx jubatus and African wild cat Felis sylvestris. 
The study was structured so that one of the routes lay directly along the Namibian border. The route in the interior, against which data from the border route were compared, started $5 \mathrm{~km}$ inland from the border, then it converged to intersect briefly with the border before it progressively swung away again from the border (Fig. 1). At its furthest point the road was $30 \mathrm{~km}$ away from the border. The route along the border was $114.6 \mathrm{~km}$ long and that in the interior was $138.5 \mathrm{~km}$ long. Long transects are better suited to detect variation in population densities of caracal than short transects, because they are likely to include the ranges of more caracals than shorter routes (Van Sickle and Lindzey, 1991). Caracal ranges in the Kalahari vary from 100 to $>300 \mathrm{~km}^{2}$ (Bothma and Le Riche, 1994; Melville, 2004). The transects were surveyed at monthly intervals for a total of 26 surveys over a total distance of $3290.4 \mathrm{~km}$.

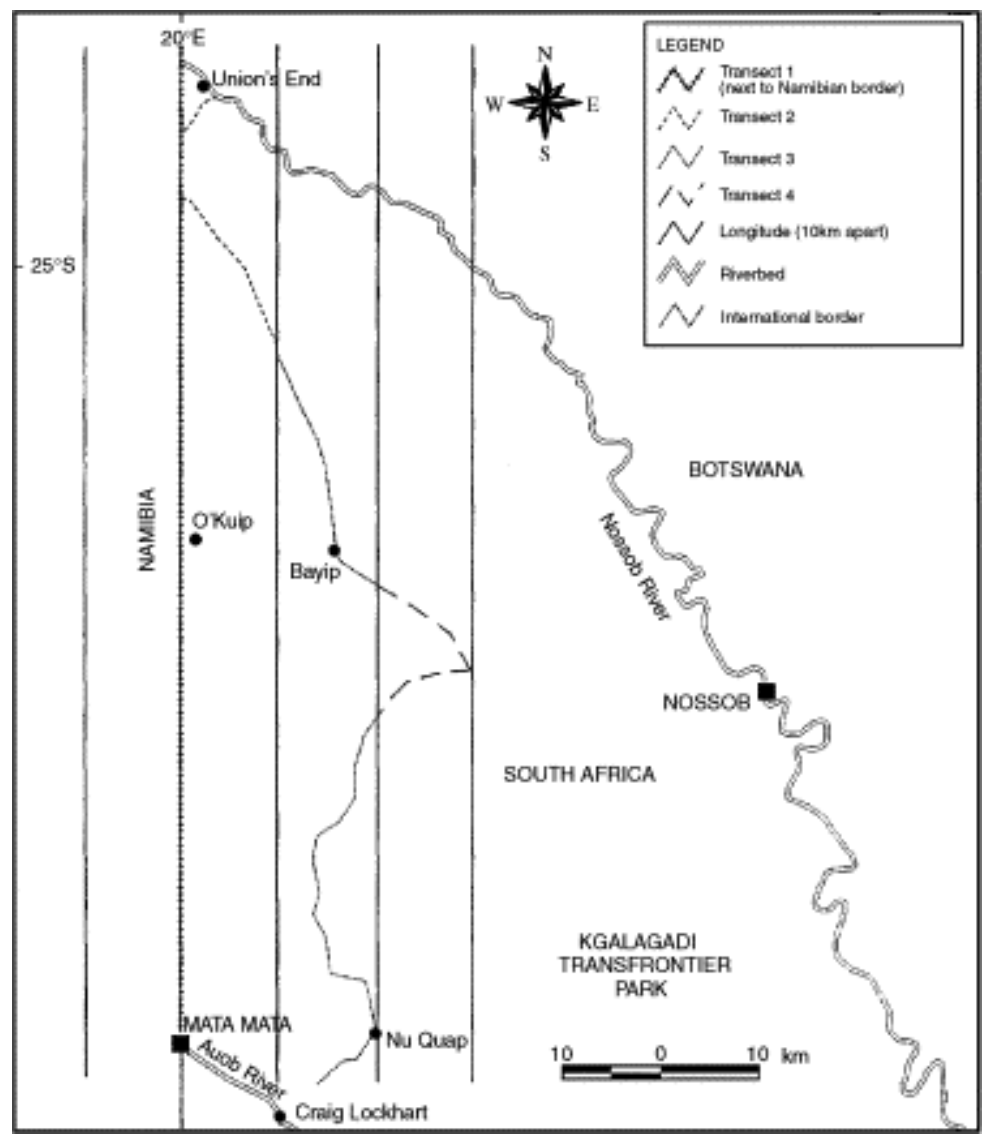

Fig. 1. Transects used for determining the relative caracal spoor density along the Namibian border and the interior of the Kgalagadi Transfrontier Park from June 2001 to July 2002.

The roads were scanned by the tracker who was seated on a tracking chair mounted on the front bumper of the research vehicle (Funston et al., 2001). To ensure that spoor were not overlooked, the transects were travelled at a constant speed of $12 \mathrm{~km} / \mathrm{h}$. It was impossible to complete both the border and the inland transect in a single day. The total 
survey was completed on two consecutive days every month. When a set of transects was interrupted by rain, both the border and interior transects were counted in successive days when ideal conditions again prevailed. When caracal spoor was encountered, the position where the spoor entered the road, the length of the discrete track sets, and the position where the spoor left the road were recorded. Additionally, the orientation of the spoor relative to the road was recorded as being either longitudinal (along the road) or transverse (crossing the road). Longitudinal spoor followed the road for a distance of at least $10 \mathrm{~m}$, while transverse spoor simply crossed the road over a distance of $<10 \mathrm{~m}$. Only spoor that were less than $24 \mathrm{~h}$ old, as indicated by the tracker (based on the guidelines of Stander, 1998), were recorded.

It was possible that an animal might move along a road, leave it for a short distance only to return to it. To avoid double-counting of such a spoor set, back-tracking of the spoor was done to the point where it originally left the transect. Where the same animal was involved, only one spoor set was recorded, and the two component distances of the spoor in the road were added. When two spoor sets were separated by $>0.5 \mathrm{~km}$, the second spoor set was assumed to have been made by a different caracal, here, independent distances were recorded for each spoor set.

The roads that diverged from the border into the interior were stratified into three separate components based on the perpendicular distance of each component away from the Namibian border. Four distinct survey areas were identified within the following distance intervals relative to the road along the Namibian border: transect 1 (along the Namibian border-114.59 km); transect $2(0-10 \mathrm{~km}$ from the Namibian border$33.52 \mathrm{~km})$, transect $3(>10-20 \mathrm{~km}$ from the Namibian border- $79.74 \mathrm{~km})$, and transect 4 $(>20-30 \mathrm{~km}$ from the Namibian border $-25.26 \mathrm{~km})$. Caracal spoor density was expressed as the frequency of spoor per $100 \mathrm{~km}$ of road surveyed, and was calculated for each of the four transects. The length of each discrete track set and the orientation of the track sets were also recorded. Spoor density, spoor orientation and the discrete track set length were calculated seasonally for a hot season from October to March and a cold season from April to September.

To maintain the integrity of the comparisons between the data that were collected along the border and those that were collected in the interior, the data were collected in a standardized manner (Thompson et al., 1998), according to a set protocol (Smallwood and Fitzhugh, 1994).

\subsection{Data analysis}

Standard $t$-tests and least square means tests were used to compare the mean spoor density along the border with that in the interior, and to compare the mean spoor densities of the transects in the interior with one another (Table 2 ). $\chi^{2}$ tests were used to compare the spoor ratio along the border transect with that on each of the transects in the interior. The spoor data from the transects in the interior were also compared with one another. The longitudinal and transverse movement patterns were compared by using $\chi^{2}$ tests to determine whether caracals tended to use the roads as corridors (Mahon et al., 1998) or 
whether they simply crossed the roads in their daily movements. These data were analysed seasonally and year-round on an inter-transect basis.

Analysis of variance (ANOVA) was applied to the discrete track set distance data to establish whether the caracals moved greater distances along the roads in the interior than along the Namibian border transect. The variance was calculated across the four road strips simultaneously, on a seasonal and year-round basis. To establish the nature and cause of any variance, $t$-tests were done to compare the border data with those of each of the interior transects. Additionally the mean discrete track set distances between transects in the interior were compared by using $t$-tests (Table 5).

\section{Results}

The spoor density varied seasonally and between the transects (Table 1). On a year-round basis and for the hot season only there was a significantly higher spoor density in the interior on transects 3 and 4 than in transect 1 (Table 2). However, there was no difference in the spoor density between transects 1 and 2 in this period (Table 2). In the cold season there was no difference between the spoor density along the border and any of the interior transects (Table 2). There was no seasonal difference between the spoor density on any of the transects in the interior (Table 2).

Table 1.

Spoor density and mean spoor length of caracal tracks on management roads in the Kgalagadi Transfrontier Park from June 2001 to July 2002

\begin{tabular}{|l|l|l|l|}
\hline Route & Season & Spoor density per $100 \mathbf{~ k m}$ & Mean track set length $(\mathbf{k m}) \mathbf{( \pm 1}$ S.E.) \\
\hline 1 & Hot & 3.39 & $1.04(0.22)$ \\
\hline & Cold & 6.40 & $1.24(0.14)$ \\
\hline & All & 5.50 & $1.19(1.13)$ \\
\hline 2 & Hot & 8.20 & $0.68(0.36)$ \\
\hline & Cold & 7.95 & $0.93(0.19)$ \\
\hline & All & 6.60 & $0.70(0.14)$ \\
\hline 3 & Hot & 8.15 & $0.79(0.16)$ \\
\hline & Cold & 9.48 & $0.64(0.08)$ \\
\hline & All & 9.07 & $0.68(0.07)$ \\
\hline 4 & Hot & 10.89 & $0.77(0.26)$ \\
\hline & & &
\end{tabular}




\begin{tabular}{|l|l|l|l|}
\hline Route & Season & Spoor density per $100 \mathbf{~ k m}$ & Mean track set length (km) ( \pm 1 S.E.) \\
\hline & Cold & 10.12 & $0.85(0.24)$ \\
\hline & All & 10.35 & $0.83(0.19)$ \\
\hline
\end{tabular}

Table 2.

$\chi^{2}$ tests to compare caracal spoor ratio and standard $t$-tests and least square mean tests comparing mean spoor density between seasons and transects in the Kgalagadi Transfrontier Park from June 2001 to July 2002

\begin{tabular}{|c|c|c|c|c|c|c|c|c|}
\hline \multirow{2}{*}{ 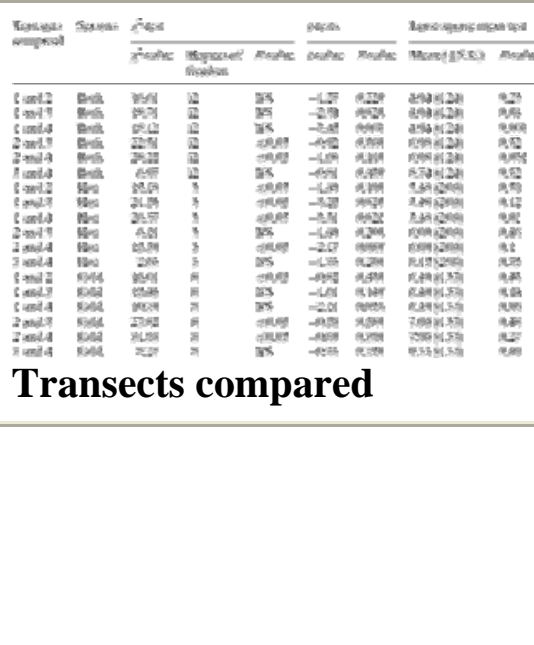 } & \multicolumn{2}{|c|}{ Seasons } & \multicolumn{2}{|c|}{$\chi^{2}$-test } & \multicolumn{2}{|l|}{$t$-tests } & \multicolumn{2}{|c|}{$\begin{array}{l}\text { Least square } \\
\text { mean test }\end{array}$} \\
\hline & & $\begin{array}{l}\chi^{2}- \\
\text { value }\end{array}$ & $\begin{array}{l}\text { Degr } \\
\text { ees of } \\
\text { freed } \\
\text { om }\end{array}$ & $\begin{array}{l}P \text { - } \\
\text { value }\end{array}$ & $\begin{array}{l}t \text { - } \\
\text { value }\end{array}$ & $\begin{array}{l}P \text { - } \\
\text { value }\end{array}$ & $\begin{array}{l}\text { Mean } \\
( \pm \text { S.E) }\end{array}$ & $\begin{array}{l}P \text { - } \\
\text { value }\end{array}$ \\
\hline 1 and 2 & Both & 16.61 & 12 & NS & -1.27 & 0.220 & $\begin{array}{l}4.94 \\
(1.24)\end{array}$ & 0.25 \\
\hline 1 and 3 & Both & 18.71 & 12 & NS & -2.54 & 0.020 & $\begin{array}{l}4.94 \\
(1.24)\end{array}$ & 0.04 \\
\hline 1 and 4 & Both & 18.12 & 12 & NS & -3.45 & 0.003 & $\begin{array}{l}4.94 \\
(1.24)\end{array}$ & 0.003 \\
\hline 2 and 3 & Both & 22.31 & 12 & $\begin{array}{l}\leqslant \\
0.05\end{array}$ & -0.92 & 0.360 & $\begin{array}{l}6.98 \\
(1.24)\end{array}$ & 0.32 \\
\hline 2 and 4 & Both & 28.22 & 12 & 0.05 & -1.68 & 0.110 & $\begin{array}{l}6.98 \\
(1.24)\end{array}$ & 0.051 \\
\hline 3 and 4 & Both & 6.97 & 12 & NS & -0.81 & 0.430 & $\begin{array}{l}8.74 \\
(1.24)\end{array}$ & 0.32 \\
\hline 1 and 2 & Hot & 15.18 & 3 & $\leqslant$ & -1.49 & 0.190 & 3.48 & 0.39 \\
\hline
\end{tabular}




\begin{tabular}{|c|c|c|c|c|c|c|c|c|}
\hline 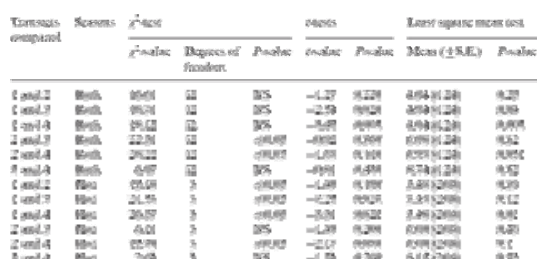 & Seaso & & $\chi^{2}$-test & & $t$-tests & & $\begin{array}{l}\text { Least s } \\
\text { mean } t\end{array}$ & $\begin{array}{l}\text { uare } \\
\text { st }\end{array}$ \\
\hline & & $\begin{array}{l}\chi^{2}- \\
\text { value }\end{array}$ & $\begin{array}{l}\text { Degr } \\
\text { ees of } \\
\text { freed } \\
\text { om }\end{array}$ & $\begin{array}{l}P \text { - } \\
\text { value }\end{array}$ & $\begin{array}{l}t \text { - } \\
\text { value }\end{array}$ & $\begin{array}{l}P \text { - } \\
\text { value }\end{array}$ & $\begin{array}{l}\text { Mean } \\
( \pm \text { S.E) }\end{array}$ & $\begin{array}{l}P \text { - } \\
\text { value }\end{array}$ \\
\hline & & & & 0.05 & & & $(2.06)$ & \\
\hline 1 and 3 & Hot & 21.53 & 3 & $\begin{array}{l}< \\
0.05\end{array}$ & -3.25 & 0.023 & $\begin{array}{l}3.48 \\
(2.06)\end{array}$ & 0.12 \\
\hline 1 and 4 & Hot & 26.57 & 3 & $\begin{array}{l}\leqslant \\
0.05\end{array}$ & -3.31 & 0.021 & $\begin{array}{l}3.48 \\
(2.06)\end{array}$ & 0.01 \\
\hline 2 and 3 & Hot & 6.11 & 3 & NS & -1.49 & 0.200 & $\begin{array}{l}6.00 \\
(2.06)\end{array}$ & 0.46 \\
\hline 2 and 4 & Hot & 15.30 & 3 & $\leqslant$ & -2.17 & 0.080 & $\begin{array}{l}6.00 \\
(2.06)\end{array}$ & 0.1 \\
\hline 3 and 4 & Hot & 2.63 & 3 & NS & -1.33 & 0.260 & $\begin{array}{l}8.15 \\
(2.06)\end{array}$ & 0.35 \\
\hline 1 and 2 & Cold & 16.01 & 8 & $\leqslant$ & -0.82 & 0.430 & $\begin{array}{l}6.40 \\
(1.37)\end{array}$ & 0.43 \\
\hline 1 and 3 & Cold & 15.43 & 8 & NS & -1.61 & 0.140 & $\begin{array}{l}6.40 \\
(1.37)\end{array}$ & 0.14 \\
\hline 1 and 4 & Cold & 10.70 & 8 & NS & -2.11 & 0.058 & $\begin{array}{l}6.40 \\
(1.37)\end{array}$ & 0.06 \\
\hline 2 and 3 & Cold & 27.82 & 8 & $\leqslant$ & -0.56 & 0.580 & $\begin{array}{l}7.96 \\
(1.37)\end{array}$ & 0.48 \\
\hline 2 and 4 & Cold & 31.98 & 8 & 0.05 & -0.89 & 0.390 & $\begin{array}{l}7.96 \\
(1.37)\end{array}$ & 0.27 \\
\hline 3 and 4 & Cold & 8.27 & 8 & NS & -0.33 & 0.750 & $\begin{array}{l}9.33 \\
(1.37)\end{array}$ & 0.69 \\
\hline
\end{tabular}


* Significant values for results of least square means tests.

NS: No significant difference for the comparison.

On a year-round basis there was no difference between the spoor ratio on transects $1,2,3$ and 4 . The spoor ratio on transect 1 was significantly different from that on transects 2,3 and 4 in the hot season. In the cold season the spoor ratio on transect 1 was significantly different from that on transect 2 , whereas that on transects 3 and 4 did not differ significantly from transect 1 . There was no seasonal difference between the relative frequencies of spoor along any of the transects $\left(\chi^{2}=2.79, \mathrm{df}=3, P>0.05\right)$ (Table 2).

On a year-round basis there was a significant difference between the mean length of discrete caracal track sets on all the transects (ANOVA: $F_{2,64}=4.35, P<0.01$ ). In the hot season there was no difference (ANOVA: $F_{2,75}=0.41, P=0.74$ ), but in the cold season, there was a significant difference (ANOVA: $F_{2,65}=4.27, P<0.01$ ). There was no seasonal difference between the mean lengths of discrete track sets along any of the transects. There also was no seasonal difference between the mean length of discrete track sets across all transects $(t=-0.71, \mathrm{df}=122, P=0.48)$ (Table 3$)$.

Table 3.

Standard $t$-test comparing the seasonal variation in the mean length of discrete caracal track sets along spoor count transects in the Kgalagadi Transfrontier Park from June 2001 to July 2002

\begin{tabular}{|l|l|l|l|l|}
\hline Transect & Cold season & Hot season & $\begin{array}{l}\boldsymbol{t} \text { - } \\
\text { value }\end{array}$ & $\begin{array}{l}\boldsymbol{P} \text { - } \\
\text { value }\end{array}$ \\
\hline & $\begin{array}{l}\text { Mean length of discrete } \\
\text { track sets (km) }( \pm \text { S.E.) }\end{array}$ & $\begin{array}{l}\text { Mean length of discrete } \\
\text { track sets (km) }( \pm \text { S.E.) }\end{array}$ & & \\
\hline 1 & $1.24(0.15)$ & $1.04(0.22)$ & 0.77 & 0.45 \\
\hline 2 & $0.68(0.19)$ & $0.93(0.59)$ & -0.62 & 0.55 \\
\hline 3 & $0.79(0.08)$ & $0.64(0.16)$ & 0.84 & 0.40 \\
\hline 4 & $0.77(0.23)$ & $0.85(0.26)$ & -0.24 & 0.81 \\
\hline Total & 0.83 & 0.92 & -0.71 & 0.48 \\
\hline
\end{tabular}

The relative incidence of caracals moving along the transects, as opposed to crossing the transects was highly variable (Table 4). On a year-round basis caracals tended to move 
along transects 1 and 2 more often than along transects 3 and 4 . Caracals therefore tended to use the transects in the interior less often as corridors for movement than the transects close to the Namibian border. In the hot season, caracals used all the transects as corridors of movement to a similar extent. However, in the cold season it appeared that the interior transects were used less often than the transects close to the Namibian border (Table 4). The ratio of longitudinal spoor to transverse spoor over all the routes was 20.3:1 in the hot season and 8.1:1 in the cold season. There was no significant difference between the frequency of longitudinal movements among the transects on a seasonal basis $\left(\chi^{2}=3.48, \mathrm{df}=3, P>0.05\right)$. However, there was a significant seasonal difference between the frequency of transverse movements among the transects $\left(\chi^{2}=62.85, \mathrm{df}=3\right.$, $P<0.05)$.

Table 4.

$\chi^{2}$ tests comparing the ratio of caracals moving along the transects to those moving across the transects, during transect counts in the Kgalgadi Transfrontier Park from June 2001 to July 2002

\begin{tabular}{|l|l|l|l|l|l|l|}
\hline Transects compared & \multicolumn{2}{|l|}{ Hot season } & \multicolumn{2}{l|}{ Cold season } & \multicolumn{2}{l|}{ Year-round } \\
\hline & $\chi^{2}$-value & $\boldsymbol{P}$-value & $\chi^{2}$-value & $\boldsymbol{P}$-value & $\chi^{2}$-value & $\boldsymbol{P}$-value \\
\hline 1 and 2 & 7.90 & $\geqslant 0.05$ & 9.53 & $\geqslant 0.05$ & 1.19 & $<0.05$ \\
\hline 1 and 3 & 3.92 & $\geqslant 0.05$ & 2.56 & $\geqslant 0.05$ & 1.93 & $<0.05$ \\
\hline 1 and 4 & 9.54 & $\geqslant 0.05$ & 8.02 & $\geqslant 0.05$ & 4.35 & $\geqslant 0.05$ \\
\hline 2 and 3 & 2.34 & $<0.05$ & 15.88 & $\geqslant 0.05$ & 5.79 & $\geqslant 0.05$ \\
\hline 2 and 4 & 0.00 & $<0.05$ & 24.40 & $\geqslant 0.05$ & 9.27 & $\geqslant 0.05$ \\
\hline 3 and 4 & 2.27 & $<0.05$ & 1.66 & $<0.05$ & 0.53 & $<0.05$ \\
\hline
\end{tabular}

The mean distance over which caracals travelled along the transects did not vary either on a year-round basis or seasonally, based on the proximity of the transect to the Namibian border (Table 5).

Table 5.

$t$-test results comparing the mean discrete caracal track set length in each spoor count transect in the Kgalgadi Transfrontier Park from June 2001 to July 2002 


\begin{tabular}{|l|l|l|l|l|l|l|l|}
\hline $\begin{array}{l}\text { Transects } \\
\text { compared }\end{array}$ & Season & \multicolumn{1}{|l|}{-test } & \multicolumn{3}{|l|}{ Mean discrete track length (km) } \\
\hline & & $\begin{array}{l}\boldsymbol{t} \text { - } \\
\text { value }\end{array}$ & $\begin{array}{l}\boldsymbol{P} \text { - } \\
\text { value }\end{array}$ & $\begin{array}{l}\text { Transect } \\
\mathbf{1}\end{array}$ & $\begin{array}{l}\text { Transect } \\
\mathbf{2}\end{array}$ & $\begin{array}{l}\text { Transect } \\
\mathbf{3}\end{array}$ & $\begin{array}{l}\text { Transect } \\
\mathbf{4}\end{array}$ \\
\hline 1 and 2 & All & 1.65 & 0.10 & 1.2 & 0.85 & $\sim$ & $\sim$ \\
\hline 1 and 3 & All & 3.61 & 0.01 & 1.2 & $\sim$ & 0.68 & $\sim$ \\
\hline 1 and 4 & All & 1.70 & 0.09 & 1.2 & $\sim$ & $\sim$ & 0.83 \\
\hline 2 and 3 & All & 0.93 & 0.36 & $\sim$ & 0.85 & 0.68 & $\sim$ \\
\hline 2 and 4 & All & 0.11 & 0.91 & $\sim$ & 0.85 & $\sim$ & 0.83 \\
\hline 3 and 4 & All & -0.72 & 0.47 & $\sim$ & $\sim$ & 0.68 & 0.83 \\
\hline 1 and 2 & Cold & 1.30 & 0.20 & 1.24 & 0.93 & $\sim$ & $\sim$ \\
\hline 1 and 3 & Cold & 3.62 & 0.01 & 1.24 & $\sim$ & 0.64 & $\sim$ \\
\hline 1 and 4 & Cold & 1.04 & 0.30 & 1.24 & $\sim$ & $\sim$ & 0.92 \\
\hline 2 and 3 & Cold & 1.44 & 0.16 & $\sim$ & 0.93 & 0.64 & $\sim$ \\
\hline 2 and 4 & Cold & 0.26 & 0.79 & $\sim$ & 0.93 & $\sim$ & 0.85 \\
\hline 3 and 4 & Cold & -0.83 & 0.41 & $\sim$ & $\sim$ & 0.64 & 0.85 \\
\hline 1 and 2 & Hot & 0.84 & 0.41 & 1.04 & 0.68 & $\sim$ & $\sim$ \\
\hline 1 and 3 & Hot & 0.92 & 0.36 & 1.04 & $\sim$ & 0.79 & $\sim$ \\
\hline 1 and 4 & Hot & 0.79 & 0.44 & 1.04 & $\sim$ & $\sim$ & 0.77 \\
\hline 2 and 3 & Hot & -0.28 & 0.79 & $\sim$ & 0.68 & 0.79 & $\sim$ \\
\hline 2 and 4 & Hot & -0.19 & 0.85 & $\sim$ & 0.68 & $\sim$ & 0.77 \\
\hline 3 and 4 & Hot & 0.07 & 0.94 & $\sim$ & $\sim$ & 0.79 & 0.77 \\
\hline & & & & & & & $\sim$ \\
\hline
\end{tabular}

Data not relevant to this comparison.

\section{Discussion}

Track counts are often the most efficient and rapid method for detecting the relative abundance of wild animals. Climatic conditions and ground conditions are limitations to 
the detectability and identification of the tracks (Silveira et al., 2003). Funston et al. (2001) indicated that population estimates based on spoor counts of small carnivores are unreliable because of the difficulty in detecting the spoor of these animals. However, provided that the detectability of the spoor remains similar in all areas, the same level of error in track detection can be expected (Burnham and Anderson, 1984). Hence estimates of population size and trends that are based on relative spoor densities are appropriate. For the caracal, such spoor counts are of great value to detect relative area use.

Mooty and Karns (1984) and Strayer (1999) concluded that presence-absence surveys should be used with caution when trying to detect population trends. Due to their relative insensitivity to small variations, spoor counts may be susceptible to Type 2 statistical errors and may tend to overestimate abundance because spoor sets from the same animal can be counted more than once in a single survey (Silveira et al., 2003). Great care, through back-tracking, was taken to ensure that this type of overestimate did not occur in the present study.

To determine whether caracals specifically moved into the adjacent agricultural area from the Park would require evidence of a cline of increased caracal activity and density from the interior of the Kgalagadi Transfrontier Park towards the Namibian border. If caracals were moving towards or were concentrating along the border to cross it into Namibia, then the incidence of caracals moving along transect 1 next to the border would be significantly less than that along the interior transects because the fence would prove to be no obstacle. Conversely, if the border fence acted as a barrier to movement, it would have been expected that the caracals would have moved for longer distances along the border road (transect 1) than along the interior ones, searching for holes in the fence through which to move or suitable fence posts over which to climb.

In the hot season, there was a low caracal spoor density along the border road relative to that found in all the interior transects, where spoor densities were at least twice that of transect 1 . Transect 4, that was furthest away from the border, had the highest spoor density in the hot season but not in the cold season (Table 1). This may indicate that during the hot season caracals did not concentrate near the border areas, but in the cold season they did so despite human activity that should have caused them to avoid the border. This indicated that there might have been a higher degree of use of the border areas, in the cold season, possibly because of reduced natural prey availability in the interior then (Begg, 2001).

Many small mammals depend on an extended hot season photoperiod as the zeitgeber for the initiation of reproduction (Lovegrove, 1999). Small mammal populations track the rainfall and primary production and in a summer rainfall area, such as the Kalahari, small mammals are more abundant in the hot season (Nel et al., 1984). The fact that small mammals generally reproduce during the hot season leads to a greater abundance of prey for the caracal during this period.

This seasonal prey variation may have caused caracals to extend their search for prey to the border areas where sheep production units are situated. That the caracals travel 
similar distances along all the roads indicated that there was an equal use intensity of all the roads (Mahon et al., 1998).

No incidences of caracals moving across the border road into or out of Namibia in the hot season were noted, based on the occurrence of spoor. However, based on spoor, in the cold season when natural prey was less abundant (Begg, 2001), crossings of the border road did occur, and then caracals may have targeted small livestock on the Namibian side of the fence. This was further supported by the overall increased frequency of movement on all the roads in the cold season, this indicated a more extensive range use in search of prey.

It has been argued by many authors that spoor counts are only useful to detect large changes in population density (Kendall et al., 1992; Beier and Cunningham, 1996; Strayer, 1999). The seasonal changes in caracal spoor density and road use that was found here confirms these arguments. Caracal spoor increased in density along the Namibian border in the cold season. These changes in intensity of road use were probably a natural response to seasonal changes in the abundance and distribution of natural prey (Begg, 2001). Moreover, sheep that were present on the Namibian side of the fence lambed in the cold season and created an additional abundant prey resource for caracals then, which may have attracted them to the border areas.

\section{Conclusions}

It is likely that caracals varied their range use in the Kgalagadi Transfrontier Park along its borders with Namibia on a seasonal basis, with an increased intensity of use of the border area in the cold season. There also seemed to be an increased incidence of border road crossings in the cold season into Namibia. This may have reflected changes in the prey abundance within the Park and a concomitant increase in prey abundance in Namibia due to small stock lambing. However, there was no change in the mean length of discrete track sets along any of the transects in either season, suggesting that caracals used the roads with similar intensity year round, irrespective of their proximity to the Parks border with Namibia.

Due to the small data set, it is possible that the results may have been affected by Type 1 errors (Beier and Cunningham, 1996) with the hypothesis that caracal density might have varied seasonally along the Namibian border being incorrectly rejected (Samuels, 1991). Any management strategies that are implemented based on these conclusions should therefore be applied with circumspection. It is therefore recommended that a long-term monitoring system of road track counts of caracal and other larger predators be implemented along the border of the Kgalagadi Transfrontier Park with Namibia, and in the immediate interior region of the Park. 


\section{References}

Begg, 2001 Begg, C.M., 2001. Feeding ecology and social organization of honey badgers (Melivora capensis) in the southern Kalahari. Ph.D. Thesis, University of Pretoria, Pretoria.

Beier and Cunningham, 1996 P. Beier and S.C. Cunningham, Power of track surveys to detect changes in cougar populations, Wildlife Society Bulletin 24 (1996) (3), pp. 540546.

Bothma and Le Riche, 1994 J.du.P. Bothma and E.A.N. Le Riche, Range use by an adult male caracal in the southern Kalahari, Koedoe 37 (1994), pp. 105-108.

Bothma and Walker, 1999 J.du.P. Bothma and C. Walker, 5. The caracal. In: J.du.P. Bothma and C. Walker, Editors, Larger Carnivores of the African Savannas, J.L. van Schaik Publishers, Pretoria (1999), pp. 117-129.

Burnham and Anderson, 1984 K.P. Burnham and D.R. Anderson, The need for distance data in transect counts, Journal of Wildlife Management 48 (1984) (4), pp. 1248-1254.

Donaldson, 2000 A. Donaldson, Born Free, Sunday Times (14 May 2000) Times Media, Johannesburg (2000).

Eloff, 1984 F.C. Eloff, The Kalahari ecosystem, Supplement to Koedoe 1984 (1984), pp. 11-20.

Funston et al., 2001 Funston, P.J., Herrmann, E., Babupi, P., Kruiper, A., Kruiper, H., Jaggers, H., Masule, K., Kruiper, K., 2001. Spoor frequency estimates as a method of determining lion and other large mammal densities in the Kgalagadi transfrontier Park. Unpublished research report to the management committee of the Kgalagadi Transfrontier Park. pp 36-52.

Kendall et al., 1992 K.C. Kendall, L.H. Metzgar, D.A. Patterson and B.M. Steele, Power of sign surveys to monitor population trends, Ecological Application 2 (1992), pp. $422-$ 430 .

Litvaitis et al., 1985 J.A. Litvaitis, J.A. Sherburne and J.A. Bissonette, A comparison of methods used to examine snowshoe hare habitat use, Journal of Wildlife Management 49 (1985) (3), pp. 693-695.

Lovegrove, 1999 B. Lovegrove, The Living Deserts of Southern Africa, Fernwood Press, Vlaeberg, South Africa (1999).

Low and Rebelo, 1996 A.B. Low and A.G. Rebelo, Vegetation of South Africa, Lesotho and Swaziland, Department of Environmental Affairs and Tourism, Pretoria (1996). 
Mahon et al., 1998 P.S. Mahon, P.B. Banks and C.R. Dickman, Population indices for wild carnivores: a critical study in sand-dune habitat, south-western Queensland, Wildlife Research 25 (1998), pp. 11-22.

Melville and H.I.A.S., 2004 Melville, H.I.A.S., 2004. Behavioural Ecology of the Caracal in the Kgalagadi Transfrontier Park, and its Impact on Adjacent Small Stock Production Units. M.Sc. Dissertation, University of Pretoria, Pretoria.

Melville et al., 2004 H.I.A.S. Melville, J.du.P. Bothma and M.G.L. Mills, Prey selection by caracal in the Kgalagadi Transfrontier Park, South African Journal of Wildlife Research 34 (2004) (1), pp. 67-75.

Moolman, 1986 Moolman, L.C., 1986. Aspekte van die ekologie en gedrag van die rooikat Felis caracal Schreber, 1776 in die Bergkwagga Nasionale Park en op die omligende plase. M.Sc. Dissertation, University of Pretoria, Pretoria.

Mooty and Karns, 1984 J.J. Mooty and P.D. Karns, The relationship between white-tailed deer track counts and pellet-group surveys, Journal of Wildlife Management 48 (1984) (1), pp. 275-279.

Nel et al., 1984 J.A.J. Nel, I.L. Rautenbach, D.A. Els and G. de Graaf, The rodents and other small mammals of the Kalahari Gemsbok National Park, Supplement to Koedoe 1984 (1984), pp. 195-220.

Samuels, 1991 M.L. Samuels, Statistics for the Life Sciences, Dellen Publishing Company, Singapore (1991).

Silveira et al., 2003 L. Silveira, A.T.A. Jacombo and J.A. Diniz-Filho, Camera trap, line transect census and track surveys: a comparative evaluation, Biological Conservation 114 (2003), pp. 351-355.

Smallwood and Fitzhugh, 1994 K.S. Smallwood and E.L. Fitzhugh, A track count for estimating mountain lion Felis concolor californica population trend, Biological Conservation 71 (1994), pp. 251-259.

Stander, 1998 P.E. Stander, Spoor counts as indices of large carnivore populations: the relationship between spoor frequency, sampling effort and true density, Journal of Applied Ecology 35 (1998), pp. 378-385.

Stander, 1997 P.E. Stander, II Ghau, D. Tsisaba, II ¥Oma and I. I Ui, Tracking and the interpretation of spoor: a scientifically sound method in ecology, Journal of Zoology, London 242 (1997), pp. 329-341.

Strayer, 1999 D.L. Strayer, Statistical power of presence-absence data to detect population declines, Conservation Biology 5 (1999), pp. 1034-1038. 
Stuart, 1982 Stuart, C.T., 1982. Aspect of the biology of the caracal (Felis caracal) Schreber 1776, in the Cape Province of South Africa. M.Sc. dissertation, University of Natal, Pietermaritzburg.

Stuart and Hickman, 1991 C.T. Stuart and G.C. Hickman, Prey of caracal Felis caracal in two areas of Cape Province, South Africa, Journal of African Zoology 105 (1991), pp. $373-381$.

Stuart and Wilson, 1988 C.T. Stuart and V.J. Wilson, The Cats of Southern Africa, Chipangali Wildlife Trust, Bulawayo (1988).

Thomson, $1992 \mathrm{R}$. Thomson, The management of pest species and of problem animals. In: R. Thomson, Editor, The Wildlife Game, The Nyala Publications Trust, Westville (1992), pp. 83-88.

Thompson et al., 1998 Thompson, W.L., White, G.C., Gowan, C., 1998. Enumeration methods. In: Monitoring vertebrate populations. Academic Press, San Diego. pp. 75-119.

Tyson, 1959 Tyson, E.L., 1959. A deer drive vs. track census, Florida Game and Fresh Water Fish. In: Communication, Proceedings of North American Wildlife Conference 24, $457-464$.

van der Walt and le Riche, 1999 P. van der Walt and E. le Riche, The Kalahari and its Plants, Pieter van der Walt \& Elias Le Riche, Pretoria (1999).

van Dyke et al., 1986 F.G. van Dyke, R.H. Brocke and H.G. Shaw, Use of road track counts as indices of mountain lion presence, Journal of Wildlife Management 50 (1986) (1), pp. 102-109.

van Sickle and Lindzey, 1991 W.D. van Sickle and F.G. Lindzey, Evaluation of a cougar population estimator based on probability sampling, Journal of Wildlife Management 55 (1991) (4), pp. 738-743. 